\title{
Financial Innovations Risk, Financial Distress and Firms Value: A Critical Review of Literature
}

\author{
Mr. Ndua Daniel Ndicu \\ Zetech University, Kenya
}

Doi: 10.19044/esj.2018.v14n10p99 URL:http://dx.doi.org/10.19044/esj.2018.v14n10p99

\begin{abstract}
Throughout history, society has always sought for ways and means of responding to life challenges and opportunities. Several scholars support the need for innovation for a firm to remain a good performer during its existence, though the level of risks associated with this kind of undertaking has not received the coveted attention. With the use of financial innovations companies can safely utilize current or go for more risky and up to date technologies that can have a drastic and positive impact on their ventures. Additionally, financial innovations have had a tremendous impact in enriching finance and enhancing the economic prosperity of many firms. However, this financial innovation may also be ruinous to the organization if it is overboard. This study thus sought to review the extant theoretical and empirical literature relating to risky financial innovations, financial distress and firm value. Specifically the study was guided by the following objectives: To review extant theoretical literature on the constructs of risky financial innovations, financial distress and firm value; to review past empirical literature on the constructs of risky financial innovations, financial distress and firm value; to identify the emerging theoretical and empirical gaps that form the basis of future research. Additionally, the study sought to propose a theoretical model to respond to the identified gaps. The study has concluded that financial innovation has positive impact on financial performance and firm value, there is direct relationship between financial innovation and financial deepening and financial innovation enhances growth of the firm.
\end{abstract}

Keywords: Innovation,financial innovations,financial distress,firm vakue

\section{Introduction}

The occurrence of the global financial crisis between 2007 and 2009 highlighted the risks of financial innovations while undermining its importance for an economy. One reason why complex financial innovation's such as collateralized debt obligations (CDOs), credit default 
swaps (CDSs) and asset securitization were developed is to help minimize the information asymmetry that are associated with credit transactions and bring about appropriate evaluation of risk. With financial innovation, firms can engage in risk ventures and reap the benefits of risk technologies that can effectively and efficiently transform their business. Additionally financial innovations have had a positive role in modernization of financial transactions and the general improvement in economic welfare (Ashby, 2010). Literature (Lisboa, Skarmeas \& Lages, 2011; Chao, Lipson \& Loutskina, 2012; Wanke, Barros \& Faria, 2015) supports that financial innovation is of great importance to a firm's performance in the future but the risks associated with this kind of undertakings have not received the much needed attention.

Innovation according to Brownbridge (2016) is a factor inherent in human development. Since time in memorial humans have sought for ways and means of responding to life challenges and opportunities many of which have led to great scientific revolutions.in addition finance has been enriched and possibilities of economic prosperity enhanced. To expound further; financial innovations comprises of activities that seek to achieve the modernization of financial systems and finance in general. (Laeven, Levine \& Michalopoulos, 2015). This idea consists of markets, institutions, practices, financial instruments and markets that new or transformed. Financial innovation may be dated back in the medieval period where organizations that were specialising in lending of money, deposits, and I Owe You (IOU, S) were established. Most of these functions were a reflection of all important functions of modern day banking. This has evolved to more recent financial innovations that include; services like ATMs, clearing houses, electronic payments, instruments of debit cards, credit cards and derivatives.

The various sources of innovations are categorized into two; technological and economic changes (Boadi, Antwi \& Lartey, 2013; Tufano, 2003). The first set includes services and products that are pegged on new technologies that decrease cost of gathering and processing information and increase efficiency in financial transactions such as mobile banking, electronic foreign exchange platforms, and automated underwriting systems. Another category consists of changes in regulation and market conditions that are faced by economic agents Such as derivatives and adjustable rate mortgages. Hence, strengthening prudential regulations that will be geared towards discouraging excessive risk can greatly benefit financial institutions.

Although there is evidence that financial innovations may improve firm performance, financial institutions may engage in innovations that may be undoing to the firm's future performance and ultimately its value (Frame 
\& White, 2014). Chao, Lipson and Loutskina (2012) studied the relationship between financial distress and risky innovation, their findings' showed that highly levered firms and those that had low book to market ratio, less cash, or poor past performance undertook risky innovation. They also found as firms move towards distress they tend to increase the more risky innovations by shifting their research activities towards such risky endeavours. This means that financial institutions including banks and financial institutions when faced by potential financial distress and bankruptcy are likely to respond by becoming more liberal by engaging in research and development to develop new systems and products so as to survive. This pursuit may lead financial institutions to engaging in innovative activities that are risky.

The conventional banking structure as noted by Calomiris (2016) is inherently unstable and significantly leads to its failure. Subbarao (2013) observes that microfinance institutions being a deposit taking institutions are likely to have fixed liabilities, at any given point in time, as fixed interest is promised on all deposits. On the other hand the assets of these institutions are in the form of loans earning variable interest which is subject to credit risk. Turner (2014) observes that this also leads to interest rate risk. In addition, the demand deposits by their nature are of short maturity while its loans take longer. There will therefore be a risk and maturity mismatch. Thus, the nature of liabilities and assets make the banking sector to be prone to failure in times of any shock or decreased confidence by the depositors (Henderson, Lang \& Jackson, 2015).

On their part, Chakravarty, Fonseca and Kaplan (2015) in their submission concluded that bank failures arise from disequilibrium's between the bank and its depositor's. Inefficiencies are brought about by the lack of coordination among the depositors hence bringing about a decline in confidence on the operations of the banking sector. However, an in-depth look into literature blames macroeconomic factors and approach and deals with the issue from an aggregate level of generalized failure. (Mare,2015). One part of this literature explains the failures in the macroeconomic imbalances. A second generation of macro models to explain financial failures suggests the central role of expectations and coordination failure among creditors, so the failure can occur independent of soundness of economic fundamentals (Kaufman, 2015). It is evident that failure of financial institutions may be caused by financial distress. The study also notes that financial innovation may lead to financial distress and in equal measure; financial distress may also necessitate financial innovation. Additionally, the study has noted that risky financial innovation and financial distress independently influence the value of the firm. However, researchers have shied away from the fact that both financial distress and risky financial 
innovation may influence the value of the firm simultaneously. Therefore, this study will seek to find out whether there is any relationship that exists between risky financial innovation, financial distress and firm value.

Financial Innovations (FI) have had numerous gains in the financial market. However, its contribution to the financial distress deserves careful evaluation. Numerous researchers have analysed the causes of financial distress (Altman, 2000; Hotchkiss, Strömberg, \& Smith, 2014;

Geng, Bose \& Chen, 2015; Zhang, Xie, Lu \& Zhang, 2015; Al-Hadi,

Chatterjee, Yaftian, Tayl or

$\&$ Monzur, 2017). They found out a number of reasons including major investors' panics, shocks to money supply, debt financing, bank customers' panics as well as the interconnectedness and with complexity of financial institutions. The updated literature however argues that a financial system that is competitive and the non-patentability of financial innovation can cause a financial distress. Tufano (2003) defined financial innovations to comprise the creating of instruments, both product and process, by inventing or diffusing services, products, or ideas. Furthermore, he emphasized the importance of developing measures for financial innovations and gives the factors behind financial innovations, namely, managing risk, pooling of funds, regulation and incompleteness of markets. Dynamic modernization takes place as people seek to satisfy new needs, reduce cost of transaction, solve agency conflict, exploit profitable opportunities and administer risks.

From the above perspectives, it therefore follows with financial innovations the general material well-being is bound to increase. In particular, an innovation plays a great role in attainment of business objectives while increasing the chances of enjoying the economies of scale (Frame \& White, 2014). Through increase of products on offer and the facilitation of financial intermediation, innovations promote a saving culture among depositors and divert these resources to beneficial projects. It also makes credit to be more accessible, make risk to be well allocated, and help match the supply risk against the demand for refinance obligations for investors willing to bear it (Geng, Bose \& Chen, 2015). Additionally, innovations may encourage improvements especially when new projects that are able to attract funding are born out of the requirements for information technology as in the case of venture capital (Sánchez, 2010).

Although banking institutions have several benefits, the leaping of these benefits has been hampered due to fact that financial institutions have faced many challenges. A big number of banks have failed due to; Poor loan quality, non-performing loans, and information asymmetry and particularly problems of adverse selection and moral hazard (Chao, Lipson 
\& Loutskina, 2012). Other reasons fronted by scholars include, heavy borrowing by directors and financial distress. All the challenges facing these financial institutions point toward financial distress (Spokeviciute, 2016). As noted by Wanke, Barros and Faria (2015), financial distress is key challenge to firms big or small. According to Betz, Oprică, Peltonen and Sarlin (2014), firms are said to face financial distress when they are faced with insolvency. Insolvency means a situation where firm is not able to meet its short-term maturing obligations or the liabilities are more than the assets. A situation where operating cash flows are not enough to satisfy short term maturing obligations and the firm is under obligation to take remedial action. Jensen and Meckling (1976) in their earlier work found out that common shareholders are inclined to take more risky investments since they are the residual claimants and thereby appropriate value from debtholders. They thus conclude that financially distressed firms are more likely to engage in risky behaviour.

Distress in the financial sector has been explained as a situation where a large percentage of financial institutions have more liabilities than assets; this might lead to runs and portfolio shifts, and subsequent downfall of the financial system (Spokeviciute, 2016). Financial sector Distress is an indicator of an unnatural situation and enormous pain in the operational activities of banks occasioned by a mixture of highly volatile factors among which are lack of continuity and unpredictable policies, management incompetence, undercapitalization, unhealthy asset portfolios caused by poor administration, fraud and forgeries. Additionally, poor loans and advances to management, interference by board members and poor internal control are other precursors to financial distress (Aburime, 2009).

Business organizations exist in the market to make worth for their stockholders. Creation of value can be described as the upsurge in the monetary worth of stockholders, as measured by proportion of marketplace worth of stocks to the net asset value of stocks, produced by the presentation of a company (Oladele, 2013). Creation of value takes place if the company produces more affluence for their bondholders that it could have not been easy to produce for themselves. To create worth, as a result, the organization needs to distinguish how to recognize, choose, as well as divide the marketplaces in which to contest; describe the kind of worth to be suggested on the market; as well as create and circulate such value (Pandey \& Saluja, 2014).

The valuation process aims at determining the current value of the projected cash flows to equity holders and converting this present value into one number that corresponds to the fundamental- intrinsic firm value (Chakravarty, Fonseca \& Kaplan, 2015).Similarly, Damodoran (2009) describes the value of the firm as the discounted cash inflows both from the 
assets in place and the likely growth in future, discounted at the cost of capital. He concludes that a firm's value can be increased by increasing the payoffs generated by the current investments, increasing the length of the high-growth period, increasing the expected growth rate in earnings or cash flows, or reducing the cost of capital.

A corporation ownership is vested in its shareholders and the shareholding' is the portion of total assets that belong to the them. The market value of each share is the price required to purchase a share in the company from the securities exchange; the share price multiplied by outstanding shares gives the market value of equity (Parkinson \& Waweru, 2010).Market value of a share is the highest price that the share will sell in a competitive market, assuming that the market participants have access to all information and act independently. This value may be established through the capital markets (Jo \& Harjoto, 2011). Since investors are assumed to be informed and can use valuation models to determine the true value of a share based on the available information, it is thus expected that market values may be derived from the company's expected long-term performance, growth opportunities, expected earnings growth and return on investment.

Widyastuti (2016) is of the view that a firm's value is the total values of all its monetary securities. The money streams received by the required claims should add up to the entire cash flow that assets produce. In a diverse situation where the company's profits vary, the problem of exploiting becomes rather complex (Ammann, Oesch \& Schmid, 2011). Value can be predicated on the dividends streams that the stockholder will receive during the firm's life, discounted to their present value. In addition, firm's value can be measured through different means such as net sales, paid-up-capital, total assets, capital employed and so on (Sharma, 2011). Firm's value is expected to reflect the value of tangible and intangible assets. The common tool which is usually used in measuring the firm's value is Tobin's Q. Tobin $\mathrm{Q}$ is usually a percentage of a firms market value of to its assets replacement cost (Taslim, 2017). Under Q proposition, a firm is said to create more value if investment returns are greater than investment cost.

\section{Research Problem}

Financial institution failures are particularly harmful for the economy and detrimental for the health of financial sector. The real cost of a bank failure is the deadweight loss and the consequent diversion in macroeconomic policy forced by the failure (Chao, Lipson \& Loutskina, 2012). Business organizations in an attempt to maximize the wealth of shareholders remain profitable and solvent always engage in research and development. In addition, the cutthroat competition in the banking sector forces financial institutions to develop unique products to remain afloat. 
This competition is more intensified between mainstream banks and other financial institutions considering that major banks have immense resources (Puma, 2011). This is catalysed by the fact that major banks, which are majority multinational, use their financial capability to edge out upcoming financial institutions (FIs). In return, financial institutions become more liberal; they lend huge amounts of money at low interest rates (Taslim, 2017). To achieve this, the MFIs borrow heavily from other commercial banks and the central bank. This in turn exposes them to credit risk, liquidity risk and default risk. Faced with the risk of bankruptcy, the MFIs engage in research and development to exploit and refine existing technologies but in the process end up engaging in a more risky search for innovative technologies that can intensely and certainly change their business.

Value of the firm as a construct has received enormous treatment in the last few centuries. Early efforts in understanding value of the firm were on articulating the value construct through conceptual reasoning. Alfred Marshall's theory of value in the 1920s is probably the earliest attempt to conceptualise the value of an undertaking (Frisch, 1950). However, this concept had its definite shortcomings. For instance, the model ignored the fact that any optimization procedure through combination of factors essentially depends on pricing system. Building on these early works, numerous studies have additionally explored the associations between firm value and other broader characteristics such as financial innovation, firm efficiency and financial distress (Norden, Buston \& Wagner, 2014). These later studies have used both theoretical thinking and empirical data to find the relationships between major constructs of the firm performance, financial distress and financial innovation. However, due to the intrinsic restrictions of the approaches used, including the adoption of largely deductive or positivist approaches to research, and the level of investigative generalization employed, most of these empirical studies have only been able to examine these relationships at an aggregate level (Widyastuti, 2016).

Although a unlimited deal of attention has been dedicated on how financial and governance features affect the general size and efficacy of innovation activity (Lisboa, Skarmeas \& Lages,2011; Sivakumar, Roy, Zhu \& Hanvanich, 2011; Frame \& White, 2014; Norden, Buston \& Wagner, 2014; Laeven, Levine \& Michalopoulos, 2015), less consideration has been given to the causes of the balance between financial innovation and financial distress and how the two affect the value of the firm. Further, there is very limited works on the degree to which companies chase more unsafe innovation. By means of existing literature that captures the degree to which financial innovations influences other constructs in the firm, this paper seek to establish whether firms facing financial distress swing the balance of their innovation toward more certain or more severe substitutes and the influence 
it has on the firm value.

\section{Empirical review Introduction}

In order to respond to the study objectives, the paper presents a summary of the conceptual literature on the constructs of financial innovation, financial distress and firm value. This will enable the researcher to come-up with a theoretical model.

\section{Risky Financial Innovations and Firm Value}

Several empirical attempts have been made to establish the relationship between financial innovation and other constructs. For instance, Lerner (2002) studied financial patents dating from 1971 to 2000.He looked at the effects of street decisions made by the state on degree observable innovations in the market. The study applied classification of Delphion IP Network and the US Patent and Trademark Office to identify 445 financial patents. The study established that there was a surge in patenting by large companies implying that patenting could be used as a proxy for financial innovation. Similarly, Lerner and Tufano (2011) established certain variances between financial innovations and inventions in manufacturing, remarkably stressing differences in changing aspects and agency structures. They pointed the challenges of evaluating financial innovations in the rarity of research and development spending, rarity of financial copyrights and the lack of transparency among private firms in their innovations.

In addition, Lerner (2006) did an investigation on the origin of financial innovations and developed measures of financial innovations basing his arguments on the news in the wall street journal for the period between 1990 -2002, which he links to more statistics emanating from the Security exchange commission, journals in finance Compustat. In His regressions he showed that less profitable companies are more inventive with an added agglomeration outcome. Boz and Mendoza (2010) did an examination on the interaction of financial innovations, learning and security constraints in a stochastic equilibrium model of domestic debt and land fees. They used an experimental system with swapping between high- and lowgeared regimes according to Bayesian learning. They established that innovations in financial markets lead to boom-bust cycles. There exist differences to innovations in product markets. In general, customers of financial facilities face opacity about the selection of financial representatives and their value delivered in financial facilities. In addition, study about financial innovation has not yet produced any structural model with which to estimate both supply and demand of financial innovations.

Lerner (2010) did a study on litigation of patents on financial 
innovations. An analysis of financial patents awards for the period 1976 to 2003 was done. Negative binomial and Poisson regressions discovered that patents on Financial inventions are contested more often than ordinary patents, contested patents were customarily from small companies and had extra claims and citations than other financial patents. Henderson and Pearson (2011) revealed that shareholders can be subjugated by innovative financial merchandises. Their event study showed that innovators supplied their inventions with a risk premium to unacquainted investors since the nature of innovativeness increases the complexity and ambiguity. Consequently, issuers abuse investors' due to their lack of knowledge and information about the operations of financial market. The authors blame investor's excess demand on framing, risk aversion and overconfidence in the financial markets.

Kuehnhausen (2014) evaluated the impact of innovative activity of financial agents on their fragility in a competitive framework. Building on the existing and vast array of the interconnection of financial innovations, financial distress of firms and financial crises provided by theoretical arguments; the study empirically assessed the causal link between a financial agents' innovativeness and stability. Using a unique data set on financial innovations in the USA between 1990 to 2002, the scholarship revealed that a greater degree of innovation negatively and positively affects firm stability after controlling for the primary firm characteristics. The results are robust compared to different modifications of innovation measures and against different fragility constraints signifying productivity, activity risk and risk of liquidation.

Norden, Buston and Wagner (2014) studied financial invention and bank behaviour as demonstrated from credit markets. This paper explored whether, and through which network, the active use of credit derivatives changes bank behaviour in the credit market, and how this channel was affected by 2007-2009 crisis. The study findings indicated that banks with superior gross positions in credit derivatives charge considerably lower corporate loan spreads, while banks' net positions are not consistently related during the crisis period. Additionally, banks with larger gross positions in credit derivatives cut their lending by less than other banks during the crisis and have consistently lower loan charge-offs. Thus, the study proposed that there are important risk management benefits from financial inventions that continue under adversative environments.

Makur (2014) evaluated the effect of financial invention on commercial bank's financial performance as the key players in the banking segment in South Sudan over a period of 5 years. The study used a casual approach and studied 16 commercial Banks registered with the central bank of South Sudan for January 2009- December 2013. The findings indicated 
that return on asset (ROA) recorded a mean of 3.2534 with standard deviation of 1.2548. The average number of daily transactions using ATM for the commercial banks during the study period was 156,547 with standard deviation of 20,51. It was clear that adoption of financial innovation resulted in robust financial outcomes of commercial banks in South Sudan.

Locally, Gitau (2011) tried to determine the association between financial innovations and financial performance of commercial banks in Kenya. He used a Quasi-experimental research design. The collected data was edited for accuracy, consistency, uniformity, and completeness and organized to permit coding and tabulation before final analysis. Qualitative and quantitative analysis techniques were used. Qualitative data was analysed by categorizing and grouping thematic contents through content analysis to address the research questions. Quantitative data was analysed through descriptive statistics such as frequency counts, mode, and median and mean where applicable. Multiple linear regressions were used to analyse the data. The study concluded that commercial banks had adopted process, product and institutional innovation. It was clear that adoption of financial innovation resulted in strong financial results of commercial banks.

Mugo (2012) wanted to investigate the impact of financial invention on the progress of Micro Finance Institutions in Kenya. A survey was carried out targeting all the thirty four registered MFIs in Kenya. After data collection, the research data was analysed in a correlation design. The research results revealed that most Micro Finance Institutions (MFIs) have innovated new services like m-banking, SME loans, emergency loans, business accounts, financial trainings and partnerships. Other institutions networked their offices, opened new branches and innovated new merchandises in a bid to grow their businesses. The research established that financial innovation is key to an cumulative development of a company in various dimensions like market share, profitability, loan sales and number of products.

Kenyoru (2013) evaluated the effect of financial innovations on financial deepening in Kenya. The study used secondary data on use of financial services. The data collected was analysed using regression method. The study concluded that financial innovation has an insignificant positive impact on financial deepening. Both mobile money innovations and mobile banking have insignificant effects on financial deepening in Kenya. This means that the rise in mobile money transactions as well as in m-banking in Kenya do not significantly influence financial deepening.

Njuguna (2015) conducted a study on the impact of provision of financial services by financial institutions in Kilifi, Kenya. A descriptive survey research design was adopted. The study outcomes showed that there was a positive correlation between the deposits mobilised and the 
financial inclusion. It was also found out that there was a need by the financial institutions to ensure that clients' deposits were kept safely in order to enhance trust from the customers. Finally, the study concluded that financial inclusion was enhanced by microfinance institutions.

Muteke (2015) studied the relationship between financial innovation and financial performance among savings and credit co-operative societies in Mombasa county Kenya. The study aimed at establishing whether institutional innovation, process innovation and product innovation influence the financial performance of SACCOs. The study used a descriptive research design. This study aimed at collecting and analysing data on the influence of financial innovation variables on the financial performance of SACCOs. The population of the study was 165 SACCOs based in Mombasa County. The study used a random sample of 36 SACCOs. Data was collected from both primary and secondary sources. The primary data was collected using a semi-structured questionnaire while secondary data was collected from the SACCOs annual reports. The results indicated that there was a positive relationship between financial innovation and financial performance of the SACCOs in the County.

Based on the reviewed literature it is evident that financial innovation influences financial performance positively or negatively. Since financial performance and firm value are related, the study makes the following proposition;

Proposition 1- Risky financial innovations undertaken will be directly associated with firm value.

Proposition 2- Risky financial innovations undertaken by the company may lead the firm into financial distress.

Proposition 3- A firm faced by financial distress may undertake Risky financial innovations to save the situation.

\section{Financial Distress and Firm Value}

Financial distress, bankruptcies and indeed forecast of corporate insolvencies has been extensively studied in the overall field of finance. There is immense literature on causes of bankruptcies and its effect on other constructs. However, majority of the studies have been conducted among banks. Further few studies have attempted to link financial distress and financial innovation and firm value.

Chao, Lipson and Loutskina (2012) conducted a study on financial distress and risky innovation. Their study sought to inspect the riskiness of innovation using a huge data set of patent holdings and a measure of riskiness centred on the degree to which new patents differ from a company's existing patent base. The researchers used data on patents between 1980 - 2002, which included 22,136 firm observations covering a wide variety of public 
companies and businesses in the United States (US). The study established that measures of financial distress, the amount of debt financing, the level of cash holdings, lower productivity, and lesser Tobin's Q, are positively connected with great distance amongst new patents and the existing patent base of a company.

Okay (2015) investigated corporate failures in non-financial Turkish firms from 2000 to 2015 . The study compared the precisions of diverse prediction models such as multivariate linear discriminant,,probit, decision tree, quadratic discriminant, , neural networks, logit and support vector machine models. This study confirms that accounting variables are powerful predictors of corporate failures one to two years before the bankruptcy. The outcomes indicate that three financial ratios: working capital to total assets, net income to total assets, net income to total liabilities are important in forecasting corporate failures in non-financial Turkish firms.

Ma'aji (2014) conducted a study on financial distress among SMES in Malaysia. The study developed distress prediction models combining financial, non-financial and governance, variables and analyse the influence of major corporate governance characteristics, including ownership and board structures, on the likelihood of financial distress. The two extensively documented approaches, MDA and logit methods were used. The study sample consisted of 172 companies with 50 percent non-failed cases and 50 percent failed cases for the period between 2000 to 2012. The results show evidence that the models serve as efficient early warning signals and can thus is beneficial for monitoring and evaluation. Controlling shareholder, number of directors and sex of managing director are found to be significant predictors of financially distressed SMEs.

Taran (2012) conducted a study on issues that can predict that a bank will get in trouble during a crisis in Ukraine. This study sought to identify early cautionary signs that could help to detect the weak banks, which would become insolvent if a crisis would come to Ukraine. The study used bank level data for the crisis periods 1997- 1998 and 2007-2008 in order to find the variables that could have been helpful for predicting banking troubles during both of these periods of financial crises. The study showed that capital adequacy and liquidity indicators are consistent predictors of banking failure across crises.

Brownbridge (1998) assessed the causes of financial distress in local banks in Africa and implications for prudential policy. The severity of bad debt problems was attributable to moral hazard on bank owners and the adverse selection of bank borrowers, with many banks pursuing imprudent lending strategies, in some cases involving insider lending. Low levels of capitalization, the political connections of bank owners, and access to public-sector deposits contributed to moral hazard. 
Locally, Murithi (2010) carried out a review on corporate improvement response by financially distressed firms listed at the Nairobi securities exchange. The study sought to discover the turnaround tactics that are taken by firms confronted by financial distress. The investigation involved all the firms that were listed for the entire period 2002-2008. Performance of the firms was established by conducting the $\mathrm{Z}$ score analysis on each of the firms. The $\mathrm{Z}$ score analysis recognized 8 companies having been financially distressed at one year or another during the study period. The investigation established that employee redundancy was the most favoured course of action being carried out followed by asset restructuring, debt restructuring and top management change. The study also established that, in the year of distress the reorganization strategies are more strengthened and are carried out less intensively in the succeeding years after distress.

Ndirangu (2011) conducted a survey on the causes of financial distress in co-operative societies in Nairobi. This study adopted a survey research design. The study had a target of 528 top management of the cooperative societies in Nairobi. Using Primary data collected using questionnaires, and descriptive statistics the study concluded that the causes of financial distress could be traced from the internal factors that heavily rely on management of co-operatives and external factors that mainly surround the politics, governance and legislation.

Muthamia (2013) studied the effect of financial distress on stock returns of firms quoted at the Nairobi securities exchange. The overall objective of the study was to estimate financial distress in the firms quoted in the Nairobi Securities exchange. Applying descriptive correlation design, the study involved a total of 26 firms selected from the population of 61 quoted firms. The study used secondary data from audited financial reports for nine years to estimate financial distress using the Altman's Z" -score model. The study found that financial distress was prevalent among the sampled firms but the estimates obtained from the sample were not significant enough to be generalized on the population. Computed stock return values were correlated with the financial distress scores. The resulting correlation coefficient indicated a weak positive correlation between financial distress and stock returns.

Meeme (2015) sought to determine the association between observance to BASEL III accord and financial distress position of commercial banks in Kenya. The study assumed a descriptive research design and the population for this study comprised of all the 43 commercial banks in Kenya. Secondary data obtained from the listed companies financial statements from 2013-2014 was used. In this study a multiple regression model was used to examine the nature of association between Basel III accord and 
financial distress position of commercial banks in Kenya. The study findings established that that capital requirements, leverage requirements and liquidity requirements have a positive relationship with financial distress status of commercial banks in Kenya hence the Basel III accord requirements positively influence the financial distress of commercial banks in Kenya.

Njuguna (2016) studied the association between risk management practices and financial distress among commercial banks in Kenya. The study was an expressive review and used auxiliary information on budgetary execution from the 43 Kenyan Commercial banks in the year 2015. The information was investigated by utilizing enlightening measurements and also inferential insights. Connection and relapse examination was utilized as a part of request to discover the level of relationship and consequently help in satisfying the motivation behind the study. The study revealed that there is a compact association between budgetary trouble and hazard management practices. This implies that financial distress of commercial banks is highly influenced by risk management practices.

From the above review of constructs, the study makes the following proposition:

Proposition 4- Financial distress is directly

associated with firm value.

\section{Theoretical Model}

The reviewed conceptual, theoretical and empirical literature in this study have brought out several constructs that will play different roles in a phenomenon involving risky financial innovation, financial distress and firm value. In view of the basic question that the paper sought to answer, scholarship needs to model the phenomenon that emerges from the interaction of these constructs. The concern that arises therefore is that of constructing a theoretical model to demonstrate the phenomenon linking risky financial innovation, financial distress and firm value. Based on the set of arguments preceding this section, the study proposes the following theoretical framework. 


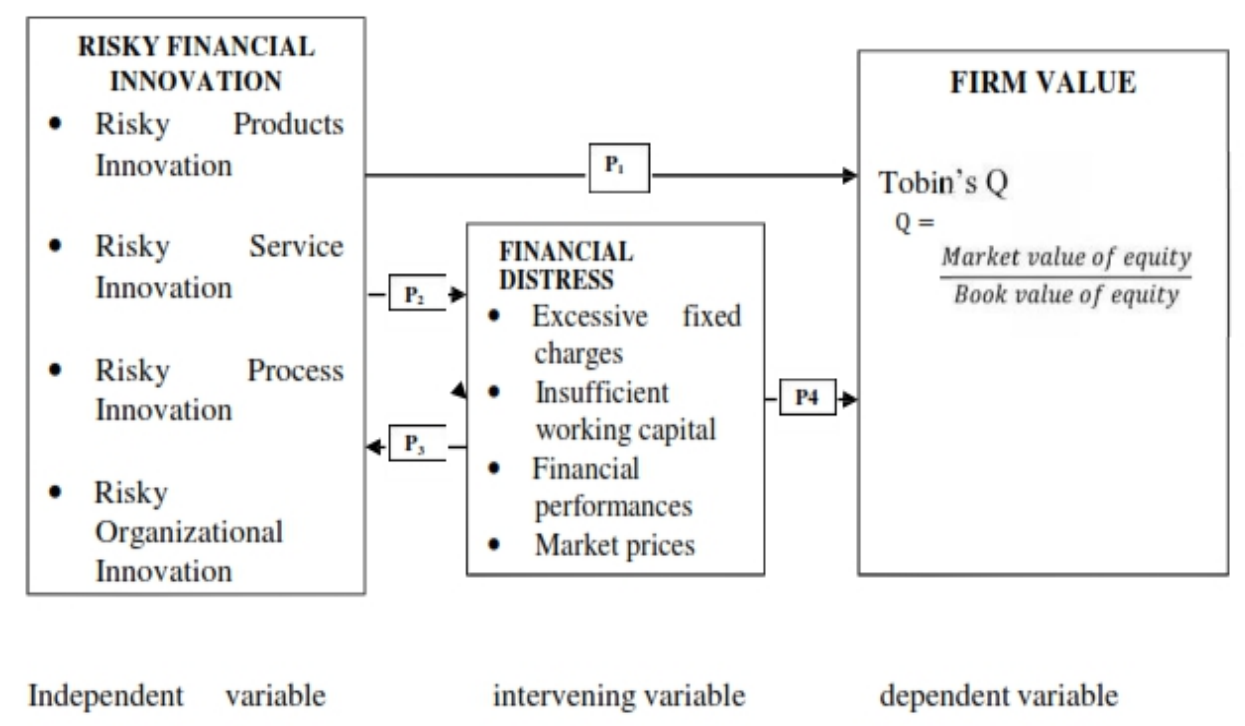

\section{Conclusion}

The resolve of this paper was the evaluation of both existing theoretical and empirical literature on the linkage between risky financial innovations, financial distress and firm value. Extant literature reviewed indicates that financial institutions sell their innovations with a risk premium due to the complexity and ambiguity involved in innovations.. This way, shareholders can be subjugated by innovative financial merchandises. Additionally, the paper has concluded that financial innovation has positive impact on financial deepening. This is achieved through mobile money innovations and mobile banking in form of money transactions as well as in M-banking. The paper also showed that financial innovation enhance growth of the firm as most Micro Finance Institutions have invented new services like m-banking, financial trainings, business accounts, SME loans, emergency loans, and partnerships. Other Micro Finance Institutions have networked their workplaces, unlocked new branches and modernized products in an attempt to nurture their firms. Moreover, the paper finds financial innovation; financial performance and value of financial institutions have a positive relationship.

However, the study noted that a larger degree of innovation beyond the optimum level exposes the firm to financial distress and negatively affects firm stability and value. It was noted that as firms engage in more and more innovative activities as indicated by the number of patented products and processes, the level of cash holdings, profitability, and the value of the firm as measured by Tobin's Q reduces. Further, the study establishes that firms faced with financial distress, result to restructuring strategies that 
are more intensified exposing the firm to innovative activities that are more risky thus engaging in risky financial innovations.

Finally, the study established that the sources of financial distress might be drawn from the internal factors that heavily depend on management of financial institutions and exterior factors that mainly border on politics, governance and legislation. The results show evidence that models such as capital adequacy and liquidity indicators consistent predictors of banking failure and therefore serve as efficient early warning signals, and can thus be beneficial for monitoring and evaluation. Additionally, little capitalization, political connections stockholders, and right to use to public-sector deposits contributed to moral hazard and subsequent financial distress.

\section{References:}

1. Aburime, U. T. (2009). Impact of political affiliation on bank profitability in nigeria. african journal of accounting, economics, finance \& banking research, 4(4).

2. Aburime, T. (2009). Impact of political affiliation on bank profitability in Nigeria.

3. Ashby, S. (2010). The 2007-2009 financial crisis: learning the risk management lessons.

4. In Financial Services Research Forum, Nottingham.

5. Al-Hadi, A., Chatterjee, B., Yaftian, A., Taylor, G., \& Monzur Hasan, M. (2017). Corporate social responsibility performance, financial distress and firm life cycle: evidence from Australia. Accounting \& Finance.

6. Allen, F. (2012). Trends in financial innovation and their welfare impact: an overview. European Financial Management, 18(4), 493514.

7. Altman, E. I. (2000). Predicting financial distress of companies: revisiting the Z-score and ZETA models. Stern School of Business, New York University, 9-12.

8. Ammann, M., Oesch, D., \& Schmid, M. M. (2011). Corporate governance and firm value: International evidence. Journal of Empirical Finance, 18(1), 36-55.

9. Babalola, S. S. (2009). Women entrepreneurial innovative behaviour: The role of psychological capital. International Journal of Business and Management, 4(11).

10. Betz, F., Oprică, S., Peltonen, T. A., \& Sarlin, P. (2014). Predicting distress in European banks. Journal of Banking \& Finance, 45, 225 241.

11. Boadi, E. K., Antwi, S., \& Lartey, V. C. (2013). Determinants of profitability of insurance firms in Ghana. International Journal of 
Business and Social Research, 3(3), 43-50.

12. Bosse, D. A., \& Phillips, R. A. (2016). Agency theory and bounded self-interest. Academy of Management Review, 41(2), 276-297.

13. Boz, E., \& Mendoza, E. G. (2010). Financial innovation, the discovery of risk, and the US credit crisis (No. w16020). National Bureau of Economic Research.

14. Hilscher, J. D., Campbell, J. Y., \& Szilagyi, J. (2011). Predicting Financial Distress and the Performance of Distressed Stocks (No. 9887619).

15. Chakravarty, S., Fonseca, M. A., \& Kaplan, T. R. (2015). Bank Runs and Regulatory Communication: An Experimental Analysis.

16. Chao, R., Lipson, M., \& Loutskina, E. (2012). Financial distress and risky innovation. Working paper, University of Virginia, Darden School of Business.

17. Ferreira, M. A., Keswani, A., Miguel, A. F., \& Ramos, S. B. (2013). The determinants of mutual fund performance: A cross-country study. Review of Finance, 17(2), 483-525.

18. Frame, W. S., \& White, L. J. (2014). Technological Change, Financial Innovation, and diffusion in Banking.

19. Frisch, R. (1950). Alfred Marshall's theory of value. The Quarterly Journal of Economics, 64(4), 495-524.

20. Geng, R., Bose, I., \& Chen, X. (2015). Prediction of financial distress: An empirical study of listed Chinese companies using data mining. European Journal of Operational Research, 241(1), 236247.

21. George, T. J., \& Hwang, C. Y. (2010). A resolution of the distress risk and leverage puzzles in the cross section of stock returns. Journal of Financial Economics, 96(1), 56-79.

22. Gertler, M., \& Kiyotaki, N. (2010). Financial intermediation and credit policy in business cycle analysis. Handbook of Monetary Economics, 3(3), 547-599.

23. Gitau, R. M. (2011). The relationship between financial innovation and financial performance of commercial banks in Kenya. Unpublished MBA project, University of Nairobi.

24. Henderson, C., Lang, W. W., \& Jackson, W. E. (2015). Insider bank runs: community bank fragility and the financial crisis of 2007.

25. Hillier, D., Grinblatt, M., \& Titman, S. (2011). Financial markets and corporate strategy. McGraw Hill.

26. Hotchkiss, E. S., Strömberg, P., \& Smith, D. C. (2014). Private Equity and the Resolution of Financial Distress.

27. Jensen, M. C., \& Meckling, W. H. (1976). Theory of the firm: 
Managerial behavior, agency costs and ownership structure. Journal of financial economics, 3(4), 305-360.

28. Jo, H., \& Harjoto, M. A. (2011). Corporate governance and firm value: The impact of corporate social responsibility. Journal of business ethics, 103(3), 351-383.

29. Kamunde, J. N. (2011). The determinants of firm value in the telecommunication sector in Kenya (masters dissertation, University of Nairobi, Kenya).

30. Kenyoru, J. O. (2013). Effect of Financial Innovations on Financial Deepening In Kenya. Unpublished MBA project, University of Nairobi.

31. Kühnhausen, F. (2014). Financial innovation and fragility. Journal of financial economics, 49(3), 283-306.

32. Laeven, L., Levine, R., \& Michalopoulos, S. (2015). Financial innovation and endogenous growth. Journal of Financial Intermediation, 24(1), 1-24.

33. Lerner, J., \& Tufano, P. (2011). The consequences of financial innovation: a counterfactual research agenda. Annu. Rev. Financ. Econ., 3(1), 41-85.

34. Lisboa, A., Skarmeas, D., \& Lages, C. (2011). Innovative capabilities: Their drivers and effects on current and future performance. Journal of Business Research, 64(11), 1157-1161.

35. Mare, D. S. (2015). Contribution of macroeconomic factors to the prediction of small bank failures. Journal of International Financial Markets, Institutions and Money, 39, 25-39.

36. Meeme, M. (2015). The relationship between adherence to BASEL III accord and financial distress status of commercial banks in Kenya (Doctoral dissertation, University of Nairobi).

37. Miller, D., \& Sardais, C. (2011). Angel agents: Agency theory reconsidered. The Academy of Management Perspectives, 25(2), 6-13.

38. Mugo, J. G. (2012). The Effect of Financial Innovation on The growth of Microfinance Institutions in Kenya. Unpublished MBA Project, University of Nairobi.

39. Murithi, M. J. (2010). A survey on corporate turnround response by financially distressed companies quoted at the Nairobi stock exchange (Doctoral dissertation, University of University).

40. Muteke, S. M. (2015). The relationship between financial innovation and financial performance among savings and credit co-operative societies in Mombasa county Kenya. Unpublished MBA project, University of Nairobi.

41. Muthamia, G. (2013). The Effect of Financial Distress on Stock Returns of Firms Quoted at the 
42. Nairobi Securities Exchange. Unpublished Master's Thesis, University of Nairobi.

43. Ndirangu, S. N. (2011). A survey into causes of financial distress in co-operative societies in Nairobi. Unpublished MBA Research Project, University of Nairobi.

44. Ndungu, C. G., \& Njeru, A. (2014). Assessment of Factors Influencing Adoption of Agency Banking in Kenya: The Case of Kajiado North Sub County. International journal of business and commerce, 3(8), 91-111.

45. Njuguna, P. G. (2015). The effect of financial services by Financial institutionson financial inclusion in Kilifi, county Kenya (Unpublished MBA Project, University of Nairobi).

46. Norden, L., Buston, C. S., \& Wagner, W. (2014). Financial innovation and bank behavior: Evidence from credit markets. Journal of Economic Dynamics and Control, 43, 130-145.

47. Nyamboga, T. O., Omwario, B. N., Muriuki, A. M., \& Gongera, G. (2014). Determinants of Corporate Financial Distress: Case of Non-Financial Firms Listed in the Nairobi Securities Exchange. Research Journal of Finance and Accounting, 5(12), 193-207.

48. Ochieng, Y. S. (2016). The Effect of Dividend Policy on the Value of Firms Listed at the Nairobi Securities Exchange. (Unpublished MBA Research Project, University of Nairobi, ).

49. Okay, K. (2015). Predicting business failures in non-financial turkish companies (Doctoral dissertation, Bilkent University).

50. Outecheva, N. (2007). Corporate financial distress: An empirical analysis of distress risk (Doctoral dissertation, University of St. Gallen).

51. Pandey, A., \& Saluja, D. (2014). Firm Value and Corporate Governance in the Indian Banking Sector: An Empirical Analysis. LBS Journal of Management \& Research, 12(1), 52-62.

52. Parkinson, J. M., \& Waweru, N. M. (2010). Paying dividends by Kenyan companies. Savings and Development, 35-51.

53. Poghosyan, T. (2013). Financial intermediation costs in low income countries: The role of regulatory, institutional, and macroeconomic factors. Economic Systems, 37(1), 92-110.

54. Ross, S. A. (1973). The economic theory of agency: The principal's problem. The American Economic Review, 63(2), 134-139.

55. Sabbaghi, O. (2015). Volatility, distress risk, and the cross-section of portfolio returns. Review of Accounting and Finance, 14(2), 149-171.

56. Sánchez, M. (2010). Financial innovation and the global crisis. International Journal of Business and Management, 5(11), 26.

57. Sharma, V. (2011). Independent directors and the propensity to 
pay dividends. Journal of Corporate finance, 17(4), 1001-1015.

58. Silber, W. L. (1983). The process of financial innovation. The American Economic Review, 73(2), 89-95.

59. Spokeviciute, L. (2016). The Determinants of Bank Failures in Normal and Crisis Times and the Resolution of Failed Banks (Doctoral dissertation, University of Leeds).

60. Subbarao, D. (2013). Banking structure in India: Looking ahead by looking back. In Speaking notes at the FICCI-IBA Annual banking conference in Mumbai, August.

61. Taran, Y. (2012). What factors can predict that bank will get into trouble during crisis (pp. 4-28). Evidence from Ukraine, KSE MA thesis.

62. Taslim, M. (2017). To Determinants of a Firm's Profitability in Food and Beverage Industry: AnEmpirical Analysis on Oriential Food Industry Holding Berhad.

63. Turner, J. D. (2014). Banking in crisis: the rise and fall of British banking stability, 1800 to the present. Cambridge University Press.

64. Tykvová, T., \& Borell, M. (2012). Do private equity owners increase risk of financial distress and bankruptcy? Journal of Corporate Finance, 18(1), 138-150.

65. Wanke, P., Barros, C. P., \& Faria, J. R. (2015). Financial distress drivers in Brazilian banks: Adynamic slacks approach. European Journal of Operational Research, 240(1), 258-268.

66. Widyastuti, P. (2016). The Influence of Financial Performance and Dividend Policy on Firm Value. Journal of Business Studies, 2(1), 16-25. 